\title{
Питання психології
}

УДК 159.922.6:159.96-053.8

DOI: $10.33099 / 2617-6858-21-64-6-71-77$

Костю С. Й. кандидат психологічних наук, дочент, Мукачівський державний університет

https://orcid.org/0000-0002-1799-4043

\section{ПСИХОЛОГІЧНІ ОСОБЛИВОСТІ ПЕРЕБІГУ КРИЗИ ДОРОСЛОГО ВІКУ}

У психологічній науці досі не вирішена проблема факторів вікових криз дорослої людини, їх місия та ступеню впливу на прояв иього феномену. Ряд дослідників віддають переваги внутрішнім факторам, в той час як інші - зовнішнім (соиіальним). Таким чином, дане питання, багато в чому, залишається відкритим.

Дана тема порушує важливі питання щодо розвитку та формування особистості. Адже, частина психологів вважає, що вікові кризи - ие ненормальне явище, а інші стверджують, що наявність вікових криз в розвитку закономірна.

Ключові слова: вікова криза; розвиток; психічний розвиток; доросла людина; особистість.

Вступ. Психічний розвиток людини відбувається нерівномірно. У ньому спостерігаються періоди відносно повільних, поступових змін, коли людина протягом довгого часу зберігає одні і ті ж основні риси, i періоди набагато різкіших, стрибкоподібних змін, пов'язаних з відмиранням, зникненням старих і появою нових психічних рис. Ці стрибкоподібні переходи називають кризами розвитку.

Теоретичне підгрунтя. Вікові кризи розвитку - специфічно-умовна індексаціяденотація перехідних фаз-етапів вікової еволюції, що розглядається в концепціях Л. Виготського, Е. Еріксона, 3. Фрейда, А. Леонтєва, Д. Ельконіна [1-2]. Криза розвитку означає початок переходу від одного етапу психічного розвитку до іншого. Вона виникає на стику двох вікових періодів і означає завершення попереднього вікового періоду i початок наступного. Джерелом виникнення кризи виступає суперечність між зростаючими фізичними i психічними можливостями людини і формами ії взаємин, що раніше склалися, 3 навколишніми людьми і видами (способами) діяльності.

У вітчизняній психології термін «вікова криза» був введений Л.С. Виготським [1].

На думку Л.С. Виготського, криза або критичний період - це час кількісних позитивних змін, результат яких - перехід особистості на нову, більш високу ступінь розвитку [2]. Згідно з Л.С. Виготським, вікова криза обумовлена виникненням основних новоутворень, які передують стабільному періоду i призводять до руйнування однієї ситуації розвитку i виникнення іншої, адекватної новому психологічному образу людини. Механізм зміни соціальних ситуацій складає психологічний зміст вікової кризи $[1 ; 2]$.

Головним завданням періоду ранньої дорослості Е. Еріксон вважає формування інтимності, яка не зводиться лише до сексуальної інтимності, а знаходить себе в дружбі, еротичних зв'язках i т.п. Іншим полюсом почуття інтимності $€$ відчуття ізоляції, яке може супроводжувати людину на всьому ії життєвому шляху.

Кризовим моментом цього періоду, на думку К. Юнга, є зіткнення людини 3 вимогами реального життя, які не завжди відповідають іiі власним уявленням. Якщо у неї є ілюзії, що контрастують 3 дійсністю, то відразу виникають і проблеми. Часто це пов'язано 3 дуже великими очікуваннями, 3 недооцінкою зовнішніх труднощів, 3 необгрунтованим оптимізмом або, навпаки, негативізмом. Молода людина починає поступово усвідомлювати, що світ - це не тільки щастя і задоволення.

Як вважають Ш. Бюлер, Р. Гаулд, Д. Левінсон, Д. Вейлант та Д.Б. Бромлей, настає період зустрічі зі супутником життя, створення власної сім’ї та народження дітей. Відсутність подібного досвіду, на думку Е. 


\section{Питання психології}

Еріксона, може призвести до замикання людини на самій собі i намаганню до уникнення контактів [2;3].

У позитивному варіанті криза завершується ухваленням відповідальності за своє життя, вибором власного шляху в житті. Суб'єктивно це переживається як поява задоволеності самим собою і своїм життям, підвищення інтересу до життя і отримуваного від нього задоволення. Деякі називають цей час «новим народженням».

Криза 25 років - перша нормативна криза віку дорослості. Вона полягає у тому, що молода людина обирає між «Я-реальним» i «Я-ідеальним» на користь першого. Фантазії, мрії юності відходять на другий план i поступаються місцем активній діяльності молодої людини, яка прагне, щоб у ії житті все було унікальне, неповторне і найкраще.

Наступна криза у віці дорослості виникає приблизно у 33 роки. На цей час людина вже має певний життєвий досвід, який допомагає їй зрозуміти, що життя не можна прожити по максимуму, що кожна людина має певні можливості, що існує безліч перешкод та обмежень у досягненні мети. Відбувається корекція планів, які особистість на цей час не реалізувала. Виникає потреба почати життя спочатку, знайти нову роботу, змінити місце проживання, розлучитися або вдосконалюватися у професійному зростанні. У цьому віці людина краще розуміє себе і визнає неповторність і індивідуальність інших [1].

Методи дослідження. В ході дослідження було використано такі методи: теоретичний аналіз, діагностичні методи, методи математико-статистичного аналізу.
Для вирішення поставлених завдань ми використали наступні методики:

1. Анкета для визначення інтенсивності протікання вікових криз дорослості.

2. Методика багатофакторного дослідження особистості Р. Кеттела - для вивчення індивідуально-психологічних особливостей особистості.

3. Методика «Книга життя», в якій використана ідея вправи, запропонованої К. Фопелем.

При виборі даних методик ми керувались такими принципами:

1. Дані методики дозволяють виявити саме те, що ми досліджуємо.

2. Вони відповідають даній віковій категорії респондентів.

3. Процедура дослідження займає небагато часу.

4. Методики легкі в підрахунках i інтерпретації.

Результати i обговорення. Отримані результати дослідження були піддані математично-статистичній обробці за допомогою комп'ютерного пакету SPSS for Windows версія 12.0.

В ході аналізу результатів респондентів, за показником кризовості, було розподілено на три групи: поверхово та глибинно кризові. Відразу нами було застосовано непараметричий критерій порівняння двох вибірок, а саме критерій Мана Уітні для визначення достовірності відмінностей між групами. Під час вирахування відмінностей між поверхово та глибинно кризовими особами, для кризи 30 років, було отримано наступні дані (таблиця 1) .

Таблиця 1.

Характеристики поверхово і глибинно кризових осіб для кризи 30 років

\begin{tabular}{|l|c|c|c|}
\hline \multicolumn{1}{|c|}{ Показник } & Поверхово кризові & Глибинно кризові & $\mathrm{p}$ \\
\hline Кількість друзів & 4,60 & 3,67 & \\
\hline Стаж стосунків з сексуальним партнером & 4,80 & 6,73 & \\
\hline Задоволеність кар'єрою & 3,73 & 2,47 & $\mathrm{p} \leq 0,05$ \\
\hline Товариськість & 8,87 & 7,93 & \\
\hline Розвиток уяви & 4,93 & 7,47 & $\mathrm{p} \leq 0,01$ \\
\hline Дипломатичність & 4,73 & 5,87 & \\
\hline Самооцінка & 8,33 & 5,87 & $\mathrm{p} \leq 0,05$ \\
\hline
\end{tabular}




\section{Питання психології}

Таким чином, для тих осіб, які гостро переживають кризу 30 років, характерна менша кількість друзів.

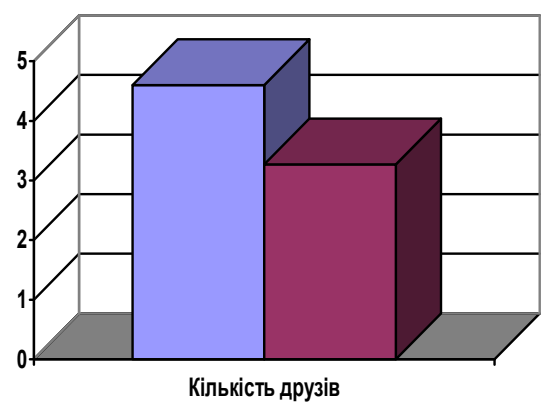

口Поверхово кризові

口Глибинно кризові

Рис. 1. Кількість друзів у поверхово і глибинно кризових

Йдеться про те, що в процесі кризи, людину, в більшій мірі, хвилює іï власний внутрішній світ: незрозумілі переживання, пошук нових способів вирішення проблем, формування нових моделей поведінки і т. д. Тому менше часу залишається для встановлення дружніх стосунків 3 оточуючими. Більш того, різкі зміни настрою (що характерно при кризі), які носять, переважно, яскраво виражений негативний емоційний характер, можуть відштовхувати вже існуючих друзів.
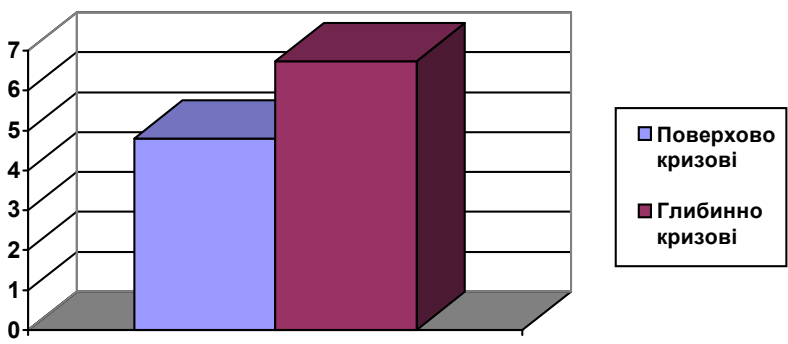

Стаж стосунків з сексуальним партнером

Рис. 2. Стаж стосунків 3 сексуальним партнером

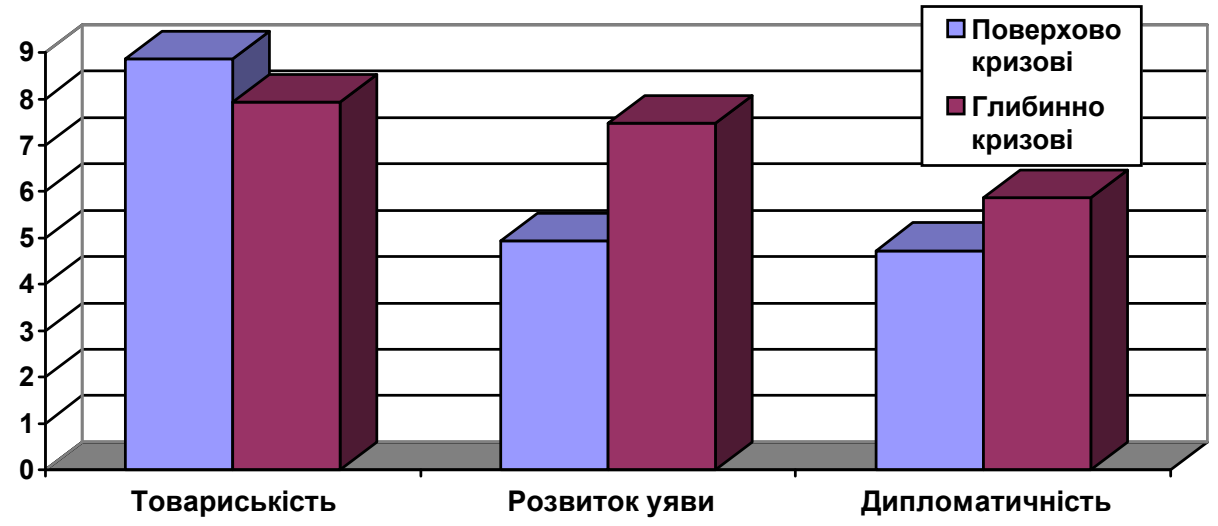

Рис. 4. Показники товариськості, розвитку уяви і дипломатичності у поверхово і глибинно кризових (для кризи 30 років)

Вісник Національного університету оборони України 6 (64) /2021 


\section{Питання психології}

Менший показник товариськості (фактор А). Йдеться про те, що криза супроводжується більшою замкненістю людини, байдужістю, певною ригідністю і надмірною суворістю в оцінці інших. Така людина скептична по відношенню до інших, надає перевагу самотності та не має близьких друзів, з якими можна бути відвертими.

Більша розвиненість уяви (фактор М). В даному випадку людині притаманна орієнтація на свій внутрішній світ і певний відхід від реальності. Вона виявляє непрактичність у вирішенні життєвих завдань і відходить від вирішення проблем у фантазії.

Більший показник дипломатичності (фактор N). В даному випадку людині притаманні обачність, що несе в собі певну обмеженість в поведінці, i раціональний підхід до подій та оточуючих. Але під час кризи дуже важливим $\epsilon$ прояв емоцій i емоційний зв'язок $з$ людьми, як для кращого розуміння своїх почуттів, так $\mathrm{i}$ для встановлення взаємин з іншими.
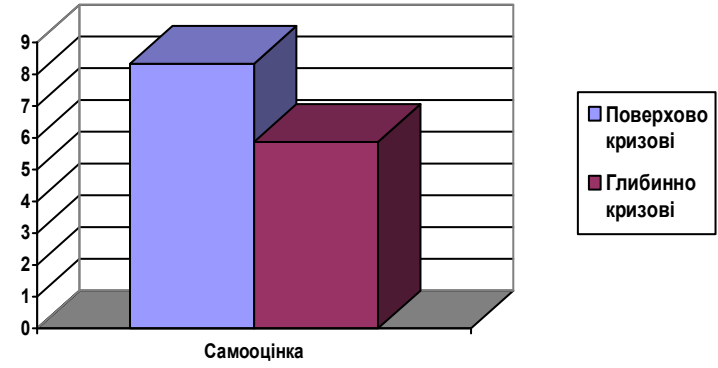

.5. Значення самооцінки у поверхово i глибинно кризових
Йдеться про те, що процес кризи самопізнання, йде по шляху заглиблення в себе і знаходження в собі все нових недоліків. Адже людина в усьому звинувачує себе: і в негараздах в сім'ї, і в проблемах на роботі, і в конфліктах з оточуючими. В результаті чого відбувається формування негативного само ставлення і людина оцінює себе нижче, ніж $\epsilon$ в реальності.

В ході вирахування середнього значення кризи 30 років для моделей поведінки було отримано такі дані (таблиця 2.).

Таблиця 2.

Середнс значення кризи 30 років

\begin{tabular}{|l|c|}
\hline \multicolumn{1}{|c|}{ Модель поведінки } & $\begin{array}{c}\text { Показник } \\
\text { кризи }\end{array}$ \\
\hline \multicolumn{2}{|c|}{ для жінок } \\
\hline 1. Турботливі & 29,31 \\
\hline 2. Або-або: заміжжя-кар'єра & 29,67 \\
\hline 3. Або-або: кар'єра-заміжжя & 29,20 \\
\hline 4. Інтегратори & 28,90 \\
\hline $\begin{array}{l}\text { 5. Жінки, які ніколи не вступають в } \\
\text { шлюб }\end{array}$ & 26,00 \\
\hline 6. Нестійкі & 31,50 \\
\hline \multicolumn{2}{|c|}{ дловіків } \\
\hline 7. Нестійкі \\
\hline 8. Замкнуті \\
\hline 9. Вундеркінди \\
\hline $\begin{array}{l}\text { 10. Чоловіки, які ніколи не } \\
\text { одружуються }\end{array}$ & 25,20 \\
\hline 11. Інтегратори & 30,00 \\
\hline \multicolumn{1}{|c|}{ Резульати досло } \\
\hline
\end{tabular}

Результати дослідження відображені на рисунку 6.

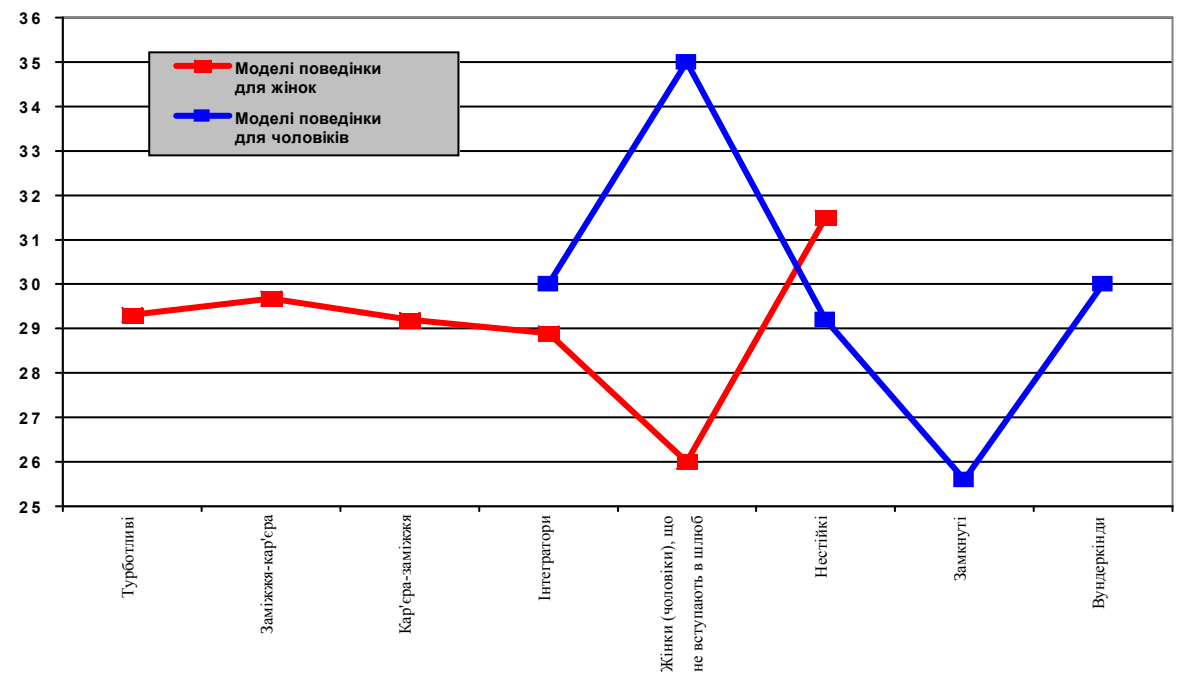

Рис. 6. Значення кризи 30 років для моделей поведінки 


\section{Питання психології}

Таким чином, моделями поведінки, що провокують більш гострий перебіг кризи 30 років $\epsilon$ :

1. Нестійкі (31,50 - для жінок). Дана модель поведінки передбачає відсутність постійності у всіх сферах життєдіяльності: кар'єрі, сім'ї, інтимних стосунках, захопленнях і т. д. Така жінка відмовляється від постійності та самовизначення, що $\epsilon$ головним завданням даного вікового періоду, і дуже гостро переживає кризу 30 років, розуміючи, що плани на життя не реалізовані.

2. Чоловіки, які ніколи не одружуються $(35,00$ - для чоловіків). В нашому суспільстві існують стереотипи, згідно 3 якими чоловіки націлені на кар'єру, а сім’і відводиться другорядна роль. Насправді, сім'я $\epsilon$ дуже важливою сферою, в якій чоловік отримує схвалення своїх досягнень, можливість проявити слабкості та отримати емоційну розрядку і підтримку. А кар'єра є засобом для утримання сім'ї та формування стабільності.

Найменш кризовими моделями є:

1. Жінки, які ніколи не вступають в шлюб (26,00 - для жінок). Дане явище пояснюється дотриманням нових форм поведінки, які характеризуються “скиданням зайвого баласту” (мається на увазі сім'я, бо вона потребує високої відповідальності та часу) і націленістю своїх природних потреб (материнський інстинкт) на оточуючих, що $є$ менш відповідальним i часозатратним процесом, в порівнянні 3 сім'єю.

2. Замкнені (25,60 - для чоловіків). Дана модель поведінки характеризується наявністю стійких внутрішніх орієнтирів, яким слідує чоловік, незважаючи на невдачі, протягом життя. Тому криза, в даному випадку, протікає поверхово або взагалі має латентний характер.

В ході аналізу відповідей респондентів на питання: чи подобається їм їх вік, і чи хотіли б вони бути молодшими або дорослішими, нами було виділено 5 поглядів на життя.
1. Філософський - найбільш позитивний погляд, який характеризується повним прийняттям i задоволеністю сучасним життям.

2. Традиційний - характеризується прийняттям сучасного життя, але бажанням здійснити певні зміни в минулому.

3. Ідеалістичний - характеризується незадоволеністю теперішнім i бажанням опинитися в майбутньому житті, яке описується більш перспективним i щасливим.

4. Ретроспективний характеризується повним незадоволенням життям і бажанням повернути минуле.

5. Невизначений - характеризується задоволеністю i сучасним i минулим, i бажанням опинитися в майбутньому.

В результаті вирахування середнього значення кризи 30 років для поглядів на життя було отримано наступні дані (таблиця 2.3).

Цікаво, що ідеалістичного та невизначеного типів на даному віковому періоді не було виявлено, що, скоріше за все, пов'язано 3 категорією віку. Адже відбувається самовизначення особистості і $є$ час та можливості для реалізації планів.

Таблиця 3.

Середнс значення кризи 30 років для поглядів на життя

\begin{tabular}{|l|c|}
\hline \multicolumn{1}{|c|}{ Погляд на життя } & Показник кризи \\
\hline 1. Філософський & 27,88 \\
\hline 2. Традиційний & 29,79 \\
\hline 3. Ретроспективний & 30,57 \\
\hline
\end{tabular}

Результати дослідження відображені в рисунку 7.

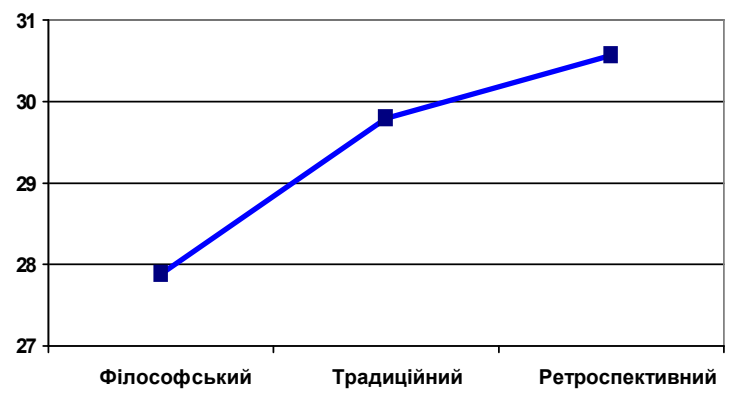

Рис.7. Значення кризи 30 років для поглядів на життя 


\section{Питання психології}

Таким чином, поглядом на життя, що характеризує більш гострий перебіг кризи 30 років, $є$ ретроспективний. Це логічно, адже під час кризи людина стикається 3 негараздами відразу у всіх сферах, і починає згадувати позитивні моменти з минулого, щоб повністю відмежуватися від існуючих проблем.

Найменш кризовим поглядом на життя $\epsilon$ філософський. У даному випадку людина адекватно ставиться до життєвих подій: насолоджуючись успіхами i намагаючись вирішувати проблеми, бо розуміє, що все залежить від ставлення людини до життєвих подій.

Висновки. Психічний розвиток людини складається із стабільних періодів, коли спостерігаються поступові зміни основних рис особистості та критичних періодів, пов'язаних 3 різким зникненням старих i появою нових психічних рис.

Криза розвитку означає початок переходу від одного етапу психічного розвитку до іншого. Вона виникає на стику двох вікових періодів і означає завершення попереднього вікового періоду і початок наступного. Джерелом виникнення кризи виступає суперечність між зростаючими фізичними i психічними можливостями людини і формами іiі взаємин, що раніше склалися, 3 оточуючими людьми і видами (способами) діяльності.

3 точки зору психології кожна криза включає i позитивні, i негативні компоненти. Успішне їх вирішення - це прогрес в розвитку особистості, можливість особистісного росту. Невирішення конфлікту - це небезпека для особистості, для iï подальшого розвитку і повноцінного функціонування.

У своєму психічному розвитку доросла людина переживає п'ять вікових криз: кризу чверті життя (характеризується зіткненням 3 реаліями життя), кризу 30 років (визначається корекцією планів), кризу середини життя (полягає в остаточному переосмисленні планів), кризу виходу на пенсію (характеризується пристосуванням до статусу пенсіонера), та кризу 60 років (характеризується підведенням підсумків та прийняттям кінця свого життя).

\section{Список використаних джерел}

1. Варбан Є.О. Стратегії і прийоми психологічного подолання життєвих криз особистості // Практична психологія та соціальна робота. - 1998. - № 8. - С. 7 - 9.

2. Когутяк Н. Становлення автентичності особистості в період життєвої кризи: концептуальна модель // Психологія і суспільство. - 2008. - № 1. - С. 115 - 126.

3. Порсева Х.О. Психічні особливості ціннісних орієнтацій людей поважного віку // Педагогіка і психологія. - 2003. - № 3 - 4. - С. 131 - 141.

\section{References}

1. Varban Ye.O. Stratehii i pryiomy psykholohichnoho podolannia zhyttievykh kryz osobystosti // Praktychna psykholohiia ta sotsialna robota [Strategies and methods of psychological overcoming of life crises of the individual // Practical psychology and social work] - 1998. - № 8. - S. 7 - 9. (in Ukrainian)

2. Kohutiak N. Stanovlennia avtentychnosti osobystosti v period zhyttievoi kryzy: kontseptualna model // Psykholohiia i suspilstvo [ Formation of personality authenticity in the period of life crisis: conceptual model // Psychology and Society] - 2008. - № 1. - S. 115 - 126. (in Ukrainian)

3. Porseva Kh.O. Psykhichni osoblyvosti tsinnisnykh oriientatsii liudei povazhnoho viku // Pedahohika i psykholohiia [Psykhichni osoblyvosti tsinnisnykh oriientatsii liudei povazhnoho viku // Pedahohika i psykholohiia] - 2003. - № 3 - 4. - S. 131 - 141. (in Ukrainian) 


\section{Питання психології}

Резюме

Костю С. Й. кандидат психологических наук, доичент, Мукачевский государственный университет

ПСИХОЛОГИЧЕСКИЕ ОСОБЕННОСТИ ПЕРЕБЕГА КРИЗИСА ВЗРОСЛОГО ВОЗРАСТА

В психологической науке ещче не решена проблема факторов возрастных кризисов взрослого человека, их места и степени влияния на проявление этого феномена. Ряд исследователей предпочитают внутренние факторы, в то время как другие - внешние (социальные). Таким образом, данный вопрос во многом остается открытым.

Данная тема поднимает важные вопросы развития и формирования личности. Ведь часть психологов считает, что возрастные кризисы - это ненормальное явление, а другие утверждают, что наличие возрастных кризисов в развитии закономерно.

Ключевые слова: возрастной кризис; развитие; психическое развитие; взросльй человек; личность.

\section{Summary}

Kostiu S. Y. candidate of psychological sciences,

\section{PSYCHOLOGICAL FEATURES OF ADULT CRISIS OVERLAY} associate professor, Mukachevo State University

Introduction. Psychological science has not yet solved the problem of factors of age-related crises of an adult, their place and degree of influence on the manifestation of this phenomenon. Some researchers prefer internal factors, while others prefer external (social) ones. Thus, this question remains largely open. This topic raises important issues of personality development and formation. After all, some psychologists believe that agerelated crises are an abnormal phenomenon, while others argue that the presence of age-related crises in development is natural.

Purpose. Identify the factors of the crisis of 30 years and the crisis of mid-life.

Methods. The following methods were used in the study: theoretical analysis, diagnostic methods: questionnaire; to study individual psychological characteristics of personality - Methods of multifactorial study of personality R. Kettel to study patterns of behavior - Methods "Book of Life", which uses the idea of the exercise proposed by K. Fopel, methods of mathematical and statistical analysis.

Originality. The research results can be used for the work of practical psychologists, social services with the appropriate category of clients

Conclusion. The factor of the crisis of 30 years is the impossibility of professional self-realization. This is due to the imitation of modern forms of behavior, according to which people strive for self-development, independence, freedom and, most importantly, competitiveness in today's mobile society.

Key words: age crisis; development; mental development; adult; personality.

Recelved/Поступила: 21.12.21. 